\title{
Metaphorizing the Holocaust: The Ethics of Comparison
}

This paper focuses on the ethics of metaphor and other forms of comparison that invoke National Socialism and the Holocaust. It seeks to answer the question: Are there criteria on the basis of which we can judge whether metaphors and associated tropes "use" the Holocaust appropriately? In analyzing the thrust and workings of such comparisons, the paper also seeks to identify and clarify the terminology and concepts that allow productive discussion.

Precisely because context is so important - and the rhetorical approach that I take attempts to understand metaphor as invoked in a specific context by a specific practitioner for a specific audience with a specific aim in mind - I will concentrate on just a few controversies involving the metaphorization of the Holocaust, primarily in Germany and Austria. My approach recognizes that cultures of rhetoric and debate - particularly, how Holocaust comparisons are made and received (including their potential for provoking scandal) - vary from society to society and from time to time (Sznaider 185,187 ). Just as it is crucial to be aware of and reflect the specificities of the events (and suffering) of the Holocaust, it is also of the utmost importance to point up the particularities of its reception and "use."

In the context of this issue and this paper, a disclaimer is in order. I, too, am using the Holocaust. As a metaphorologist, I have asked myself whether I am using the Holocaust to explore issues of how the process and rhetoric of metaphor operate (in which case the Holocaust would be the vehicle of my analysis and subservient to the end of contributing to metaphor theory); or whether I am using my understanding of metaphor to shed light on how the Holocaust is (and might ethically be) metaphorized. The question is important in terms of self-knowledge and ethical disclosure, but it also signals the importance of taking into account the directionality of comparison - what is projected onto what - an issue that will arise again later in the paper.

Given the prevalence of comparisons invoking the Holocaust Samantha Power speaks of "Holocaustizing" - it is surprising how contested the comparability of the Holocaust continues to be (Power 32). These days, the refusal to entertain the possibility that Holocaust comparisons might be appropriate and principled is both rare and doomed to failure on both pragmatic and logical grounds. Even the contention that something is unparalleled, unprecedented, or unique requires a previous comparison to establish its special standing (Bauer 39).
Images

vol.VIII/no.15-16

Poznań 2011

ISSN 1731-450X
1. The (In)Com-
parability
of the Holocaust 
It is clear that to be unprecedented is not the same thing as to be unique, although the two concepts often occur in the same contexts when referring to the Holocaust. It is also clear that there may be "stakes" in insisting on either or both. But it is difficult, these days, to find someone who objects on principle to any and all comparisons of the Holocaust with other events or phenomena on the grounds that they necessarily falsify history and/or demean the suffering of those who experienced the Holocaust.

The absolute rejection of Holocaust comparisons figures most prominently in the arguments of those who oppose such putative prohibitions. Those who summarily dismiss the claim that the Holocaust was unique and/or unprecedented, usually do so on the erroneous grounds that this claim excludes comparisons, privileges Jewish suffering over those of other groups or in other genocides, and stands in the way of a "universalistic" understanding of the Holocaust's significance. The more sophisticated arguments of this kind take into account the historical, social, and cultural context in which these receptions take place; Dan Stone's and Jeffrey C. Alexander's come to mind here (Stone), (Alexander). [1]

Those who argue in favour of seeing the Holocaust as a unique event have, at least in terms of logic, an easier time of it. For it is evident that every event or phenomenon, particularly one so complex as the Holocaust, is unique. To say so is, in one sense, merely to state the obvious. Here, too, of course, context and intention play a role - for the statement of the Holocaust's uniqueness is also part of a larger argument whose own particularities must be taken into account in order to understand and evaluate it.

Some have argued from numbers of victims. Others, like Eberhard Jäckel, have offered a definition based on the policies of the National Socialist state, the compass of the victim group, and the means of mass murder by which the genocide was perpetrated (Jäckel esp. 118). More recently, Avishai Margalit and Gabriel Motzkin have offered a new and provocative analysis of what makes the Holocaust unique. They reject arguments that the Holocaust's uniqueness stems from any incomparability or unprecedentedness. Rather: "What is unique about the Holocaust is its particular fusion of collective humiliation and mass destruction. (...) Since the Nazis had a unique racial conception of their Jewish enemies as questionably human, they devised a unique fusion of humiliation and death in order to destroy them" (Margalit and Motzkin 65-66).

According to Margalit and Motzkin, "the Jews were much less unique than the Germans," and the theory and practice of the National Socialist genocide against the Jews combined to create a unique situation by which the Germans, "more radically than anyone else in the

[1] An example of a less sophisticated approach is Norman G. Finkelstein's The Holocaust Industry; see (Alexander, pp. 87-88 [part of n. 57]) and (Sznaider). 
last several millennia, (...) denied the idea of a common humanity" (83). It is significant that Margalit and Motzkin, at the same time as they insist on the uniqueness of the Holocaust, construe it as inherently comparable. They do this, first, through a revealing phrase - "more radically than anyone else in the last several millennia" whose syntax and meaning is explicitly comparative, even as it purports to establish uniqueness. Second and more important, they make the denial of humanity the central point in their analysis, and they see the Holocaust as a "constitutive story" that establishes and marks a "dis-continuity" in human history (83). Importantly, Margalit and Motzkin emphasize the centrality of humanity and therefore of empathy (or its lack) in the perpetration and understanding of the Holocaust.

The comparability or incomparability of the Holocaust has also been debated in terms of the conventions and expectations of "text types" such as historiography and imaginative literature. Here it is not so much a question of persuading an audience of the particularistic or universal nature of the Holocaust, but of the appropriateness of using metaphor and related tropes to explain the Holocaust. And yet, what might seem like the more technical question (to metaphorize or not to metaphorize) is linked with the ethico-political question of uniqueness.

The connection is enunciated clearly in Wulf Kansteiner's essay "The Rise and Fall of Metaphor: German Historians and the Uniqueness of the Holocaust." Kansteiner argues that (1) metaphorical language is inimical to, and dangerous for, historical discourse; and (2) the parties to the Historians' Dispute [Historikerstreit] in the 1980s, foremost among them the proponents of the Holocaust's uniqueness, resorted to metaphor as a delayed psychosocial reaction to their generation's adolescent experience with National Socialism and the destruction it wreaked (Kansteiner 237).

It is worthwhile examining Kansteiner's understanding of metaphor. Straining Roman Jacobson's well-known distinction between metonymy (linkage of two terms based on their contiguity) and metaphor (linkage of two terms based on their similarity), Kansteiner holds the former to "reflect actual existential contiguities of past worlds, or at least contemporary perceptions of such contiguities." Metaphor, on the other hand, figures in texts that "are not driven by real or perceived contiguity but by imagined similarity" and hence are "much more subjective texts which potentially defy comprehension" (Kansteiner 222-223). Kansteiner's notion of metaphor as substitution and as an operation that defies interpretation and so disrupts the reality-based nature of historical discourse is outdated and flawed, but nevertheless provides productive food for thought (Kansteiner 237-238). While it is true that some metaphors "defy comprehension," most metaphors, though subject to interpretation, do not behave this way. 


\section{How Com- parison Works: Metaphor, Metonymy, Synecdoche}

Scholars of metaphor agree that "it takes two to tango." That is, metaphor is a process that occurs in and through the connecting of two elements that are not assumed to be linked conceptually. In this process, aspects of the "vehicle" domain are mapped onto corresponding aspects of the "tenor" domain. [2]

Scholars also tend to explain metaphor through metaphor. Often the terminology comes from the conceptual / lexical domain of visuality. Thus, scholars at the University of Bochum have invoked the notion of Baroque emblems in which a visual image ("pictura") is explicated through its being linked with an explanatory text beneath it ("subscriptio") (Wülfing et al. 115, esp. n.8). Similarly, Paul Ricoeur follows Marcus B. Hester in explaining metaphor as a process of "seeing as." [3]

To metaphorize, then, is to see one thing in terms of another, "from one point of view, not from all points of view" (Ricoeur, Metaphor 212).

Two aspects of these approaches deserve special mention. First, neither Wülfing et al. nor Ricoeur suppose that one term of the metaphor replaces the other in an act of substitution; rather, the two terms enter into a syntactic relationship with one another, in the process of which something new emerges. Thus, metaphor is seen as a process rather than a product, although this process is then enacted in the form of individual metaphors. Second, when $\mathrm{X}$ is seen as $\mathrm{Y}$ (or, to turn it around, $\mathrm{Y}$ is projected onto $\mathrm{X}$ ), it is not the case that "all of $\mathrm{Y}$ " applies to X. As Ricoeur says, both the author of the metaphor and its recipient invoke a system of filters (not always the same one!) that determine in which respects the projection applies.

An early proponent of the "interaction" theory of metaphor, in which the "focus" of the metaphorical expression interacts with the "frame" to produce a new meaning, was Max Black, on whose theories Ricoeur also draws. Black's "system of associated commonplaces" helps to explain the mechanism - individual and cultural - by which the filtering, highlighting, and suppression of possible metaphorical meanings operates, as features are selected from a conceptual lexical domain (for example: photography, with its focusing and framing) and applied to the subject at hand (Black 287).

Two aspects of metaphor require elucidation here. First, metaphor is not merely ornamental (although it can function this way in some texts), but presents an argument that is a story and can, especially in the kinds of situations on which this paper focuses, itself be the object of contention. Second, metaphor is not always linguistic. It can
[2] In speaking of the "tenor" and "vehicle" of a metaphor I am using the most prevalent terminology in English. To give a mnemonic example, in the conventional metaphor "the ship of state," the ship is the "vehicle" and the state the "tenor."
[3] The reference is to Marcus B. Hester, The Meaning of Poetic Metaphor: An Analysis in the Light of Wittgenstein's Claim that Meaning Is Use, De Proprietatibus Litterarum. Series Maior 1 (The Hague: Mouton, 1967). 
also be realized through visual images or objects, either by themselves or in conjunction with texts. Metaphor could also be enacted through other arts, including music. If for example, the sounds of the "HorstWessel-Lied" were played to accompany images of other marchers (Saddam Hussein's Republican Guard or Israeli soldiers), the metaphor would project aspects of National Socialism onto the other realm so as to constitute an argument with a truth claim, however valid or invalid.

Although the musical example is something I just invented, combinations of visual and textual metaphor are not unusual and instantiate the structure of the emblem to which Wülfing et al. refer. Take, for example, a full-page display advertisement in the Canadian magazine Adbusters under the headline "Truthbombs on Israeli TV”. The advertisement, on behalf of memewarriors@adbusters.org, seeks donations to sponsor 30-second spots on Israeli television. The spots' content is not further specified, but the bulk of the page consists of six photographs (three rows of two columns each). The photographs in the left column are in black-and-white; those in the right column are in colour. Under each row is a caption (subscriptio) describing the photographs of that row, the left-hand column first. The caption for bottom row is indicative of the advertisement's thrust: "Young Jewish boys in Warsaw sneak over the ghetto's wall to bring back food. A young Palestinian smuggles a sheep into Gaza through an underground tunnel" (Truthbombs).

I will not analyze the operation of the advertisement in detail, except to point out that it works metaphorically. Palestinians in Gaza are "seen as" Jews - "resistance fighters" and children - in the Warsaw Ghetto under National Socialism. Sentence pairs in each caption constitute a metaphor on their own, bringing as they do the two situations into relation with each other and inviting the reader to provide the relevant points of comparison. The same is true for the photographs, which convey both content and emotional impact. A remarkably similar advertisement by B'nai Brith Canada - though with a predictably opposite message - features a picture of Hitler in conversation with the Grand Mufti of Jerusalem. The message is that Hitler's murderous character lives on today in "radical Islam," transmitted through his ally.[4]

It is one thing to print a photograph of Hitler conversing with the Grand Mufti. It is something else to assert that a political or historical figure is a "second Hitler." This mapping would seem to be unidirectional in that, had someone in early 1991 (after Iraq had launched missiles against Israel) called Saddam Hussein "Hitler's re-

[4] Space limitations preclude a detailed comparative analysis here, except to note that metaphorical

"vehicles" drawn from the Holocaust can be applied

\section{Visual and Textual Metaphor}




\section{The Return of Hitler?}

venant," the metaphor would be read to impugn only Saddam's, and not Hitler's, "reputation." [5]

The question would then be whether such an attribution were justified in the main, and which aspects of the two men it invoked. But there would be no question about the metaphoricity of the attribution: The reference to a reborn, or never-dead Hitler would not be understood literally. Or would it?

My conjuring up Saddam Hussein as Hitler's revenant is not a fantasy. It refers to an incident that exercised the German political and intellectual public in early 1991.[6]

The man who called Saddam Hussein "Hitler's revenant" [Hitlers Wiedergänger] was the well-known author Hans Magnus Enzensberger, whose opinion piece appeared under that title in the weekly newsmagazine Der Spiegel on 4 February 1991 (Enzensberger).

Enzensberger's piece reflects a consciousness (and self-consciousness) about the contentious and contextualized nature of such comparisons. He acknowledges that, in the Federal Republic of Germany, comparisons invoking National Socialism have often served a relativizing and hence exculpatory purpose. Though this has led to such comparisons' being considered taboo, he confesses to seeing no other way of understanding historical events except through comparison. But he rejects the notion that his calling Saddam Hitler's revenant is "journalistic metaphor" or "propagandistic exaggeration." In a move of which Kansteiner would approve, he thereby relegates metaphor - at least of the sort one encounters in journalism - to the realm of propaganda and exaggeration for effect. To the vices of metaphorical usage he juxtaposes the virtue of genuineness, asserting that Saddam really is the ghost of Hitler past.

But Enzensberger is not done with metaphor yet. Although he avoids using the term he has stigmatized, preferring instead the more neutral "comparison" [ Vergleich], he both invokes and explicates a complex (and interesting) sense of metaphor. The crux of the matter lies not only in naming Saddam Hussein for what he is (or what Enzensberger imagines him to be), but in the proposition that if the ghost returns, it recalls its past life, too. The direction of the metaphorical transfer or projection (Saddam today is a kind of Hitler then), when combined with the system of associated commonplaces, is capable of a reversal that reflects (in both senses) on the Federal Republic: Saddam's society today is a kind of Germany then - or also now?

Enzensberger argues that any comparison between Hitler and Saddam necessarily implicates a second comparison between the so-
[5] According to The New Shorter Oxford English

Dictionary (Oxford: Clarendon Press, 1993), a "revenant" is "a person who has returned, esp. supposedly from the dead; a ghost." The French-derived
English term, like the German, suggests someone who has "returned" (from the dead).

[6] I am indebted here to Moshe Zuckermann's discussion (Zuckermann). 
cieties that placed themselves at their dictator's disposal, only to be slaughtered. In a stern rebuke to Germany's political right and left, he demands that Germans "recognize themselves in the Arabs" (28) as a people who have been drawn to dictatorship out of a sense of historical injury and in their inherent racism.

When Enzensberger writes that his first metaphor implies a second, that "the Germans were the Iraqis of 1938 to 1945," he refers to a "Rückschluß" - a conclusion that comes about when the direction of the metaphorical mapping (Saddam is a kind of Hitler) is reversed and its force ricochets back, mapping out aspects of Iraqi and Arab society on the Germans of today.

A month later, Enzensberger's article received a sharp rebuke of its own in a commentary by the publisher of Der Spiegel, Rudolf Augstein, who pointed out the differences between Saddam Hussein and Hitler (Augstein). The same issue also featured a longer analysis of Enzensberger's claims by the essayist Cora Stephan. The title of her article, "On the German Home Front," is itself a metaphor whose doubleness speaks to the situation in Germany during both the Gulf War just ended and World War II, Hitler's war. Stephan seizes on the fact that "historical analogies" are flying, and not just from Enzensberger - and infers from this that the German public is concerned that its past is about to be flung in its face (Stephan 238).

Stephan rejects Enzensberger's comparison of Saddam to Hitler on the grounds that it represents either "an impermissible demonization of Saddam - or a relativizing of the singularity of German crimes" (242). But Stephan is aiming not just at Enzensberger; she is also concerned that the "Left" is also digging into the grab-bag of historical analogies to demonize the Americans.

The metonymy in question is "Dresden" - which is conventionally invoked by the German Right to suggest that, since the Allies allegedly committed war crimes by bombing civilian areas without military significance, German war crimes must not be "incomparably evil" (245).[7]

Specifically, Stephan muses, the mention of Dresden shows that the civilian victims of the bombings of Bagdad function as surrogates for the dead of Dresden that have been repressed parts of German collective memory.

In addition to demonstrating some of the main ways in which Holocaust comparisons work in Germany - including the ways in which they are reflected at a meta-level - the articles by Enzensberger and Stephan make clear the extent to which metaphor and metonymy operate in a rhetorical setting. By this I mean that the metaphor is not

[7] There is an entire literature on the bombing of Dresden in February 1945, and the matter is too complicated to address here. And the Americans, too, Stephan reminds her readers, are fond of metonymies
- for example "Munich," which has become the conventional admonition to those who favour the "appeasement" of dictators over "intervention" (242). 


\section{Metonymy and Synecdoche}

substitution, nor is it without a truth-claim; rather it is the core and evocation of a narrative argument - the means, in other words - by which the author seeks, in a particular context, to persuade a particular audience of a particular point.

So far, I have been discussing metaphor as a generic concept that subsumes metaphor proper as well as metonymy and synecdoche. Now I will complicate matters by providing some working definitions of the latter two phenomena, noting at the outset that it is often difficult if not impossible to determine which is at work. All three operations involve establishing or revealing a connection between two terms (vehicle and tenor) and the lexical / conceptual domains and system of associated commonplaces that are attached to them. Metaphor proper involves the highlighting (or creation) of similarities between the two domains, whereby, as A.E. Denham reminds us, "similarity' is itself a response-dependent concept: the property of similarity is not something that applies to objects independently of our finding them so" (Denham 294).

Traditionally, metonymy is seen to connect the terms by virtue of one's being the creator, proprietor, container, resident, product, or cause of the other's creation, property, content, residence, material, or effect. In synecdoche, on the other hand, one term is a part of the other's whole (Kubczak 95-96). Sometimes, however, metonymy and synecdoche are lumped together, with the part/whole relationship seen as another subcategory of what Jakobson, and following him, Kansteiner, consider contiguity relationships.

George Lakoff and Mark Turner are proponents of a theory of metaphor as a process of conceptual mappings that determine how we think. But the larger issue of their theory is not at stake here; more interesting for us is their way of distinguishing metaphor from metonymy/synecdoche. In the section of their book devoted to metonymy (synecdoche does not figure in their scheme, being included under metonymy, but I will retain it for reasons that will become evident later), they compare and contrast metaphor and metonymy in a way I have distilled in the following table (Lakoff and Turner 103):

\begin{tabular}{lll}
\hline & Metaphor & Metonymy \\
\hline Conceptual domains & $\begin{array}{l}\text { two - "one is understood in } \\
\text { terms of the other" } \\
\text { "a whole schematic structure ... } \\
\text { Schematic structures }[8]\end{array}$ & $\begin{array}{l}\text { one - the "mapping occurs within } \\
\text { a single domain, not across domains" } \\
\text { "one can refer to one entity in } \\
\text { schematic structure" }\end{array}$
\end{tabular}

[8] The schematic structures to which Lakoff and Johnson refer are the organizing structures within the conceptual domains, similar to Black's system of asso- ciated commonplaces, although the latter is more at the level of parole, whereas the schemata operate at the level of langue. 
Logical mapping[9]

Nature of the beast

Operation "the logic of the source domain is mapped onto the logic of the target-domain structure"

conceptual

mapping from $\mathrm{A}$ to $\mathrm{B}$ "one entity in a schema is taken as standing for one other entity in the same schema, or for the schema as a whole" conceptual mapping from $\mathrm{A}$ to $\mathrm{B}$

Another instance of contested Holocaust comparison involves the importation to Europe of a travelling poster display, "Holocaust on Your Plate," by the animal rights group PETA (People for the Ethical Treatment of Animals). The German-language version, with the title "Der Holocaust auf Ihrem Teller," was unveiled in March 2004. In both the English and German version, the display consisted of eight posters, the first seven of which became the primary focus of court challenges in Germany and Austria (BVerfG), (OG).[10]

The structure of the first seven posters was consistent and will be familiar from the earlier discussion of the Meme Warriors and B'nai Brith advertisements: Underneath a headline were two photographs - on the left, a black-and-white photograph of concentration camp inmates and corpses; and on the right a colour photograph of animals (alive and dead) that corresponded in some way to the photograph on the left, as the following illustration shows.[11]

\section{Holocaust Comparison in the Courts}

The headlines were as follows:

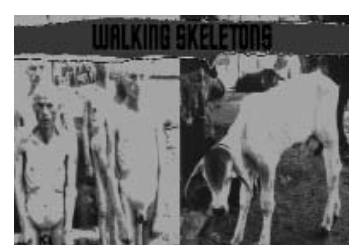

\begin{tabular}{lll}
\hline Poster & English & German \\
\hline 1 & Walking Skeletons & Wandelnde Skelette \\
2 & The Final Indignity & Endgültige Demütigung \\
3 & The Road to Hell & Die Fahrt in die Hölle \\
4 & Mass Murder & Massenmord \\
5 & Baby Butchers & Kinder-Schlachter \\
6 & To Animals, All People Are Nazis & Wo es um Tiere geht, wird jeder zum Nazi \\
7 & The Holocaust on Your Plate & Der Holocaust auf Ihrem Teller \\
\hline
\end{tabular}

Members of the German Jewish Community sought to have the exhibition banned. After losing both the initial case and an appeal, PETA sought leave to refer the case to Germany's highest court, the Federal Constitutional Court [Bundesverfassungsgericht], which, however, declined to hear it in its ruling of 20 February 2009. In Austria,

[9] The source domain corresponds to the vehicle/ focus of a metaphor; the target domain to the tenor / frame.

[10] In citing the decisions, I use the abbreviations BVerfG for the German court (with paragraph numbers) and OG for the Austrian court (with page numbers). For a legal analysis of the Austrian case, see (Thiele).
[11] The English-language version is available in pdf-format (The Holocaust on Your Plate). The eighth poster does not follow the same format and consists of a picture of a cow and commentary, along with Web links and a plea to adopt a vegetarian diet. As a result of the lawsuit, the German version is not available on the Web. 
a similar complaint also succeeded at the initial and appeals level. PETA's appeal then made its way to the the Austrian Supreme Court of Justice [Oberster Gerichtshof] which issued its ruling on 12 October 2006, almost two and a half years before the decision of its German counterpart.

In this section of the paper I want to analyze the arguments of three sets of actors in the dispute: (1) PETA in North America and Europe, through the exhibition itself, statements by officials, and pleadings before the courts; (2) those who sought to have the posters banned; and (3) the courts. Throughout, I will refrain from arguing for or against the exhibition; rather, my intention is to develop points relevant to the overall consideration of metaphors of the Holocaust in preparation for Part 4 of my paper, on the ethics of Holocaust comparison.

The case hinged on a relatively small number of disputed issues, some of them technical but most of them substantive.

1. Did the original complainants in each case have standing before the court?

2. In the German case: Are the persons depicted in the posters Jews, and is the meaning of the term "Holocaust" restricted to the genocide against Jews?

3. Did the posters in effect equate Holocaust victims with animals?

4. Do images have the same potential to violate personal rights as actions and words?

5. Is comparing the Holocaust to the situation of animals in industrial livestock farming insulting or demeaning to humans? In the German case: If so, does the injury contravene the constitutional protection of human dignity?

6. If the exhibition constitutes protected speech, are there sufficient grounds for holding that other societal interests outweigh this protection here?

I will comment only on those that are relevant to the present discussion.

The Austrian lower courts had accepted the complainants' standing, but the Supreme Court overturned this, finding there was no way of knowing whether this group of complainants actually represented the collective in whose name they claimed to speak (OG p. 4). With this, the remaining questions had become moot, although the court went on to comment on them. In the German case, all courts found that the complainants did have standing. In fact, the Federal Constitutional Court explicitly confirmed and extended to this case a previous decision that Holocaust denial constituted an infringement of the personality rights of Jews today (BVerfG par. 26).

The nature of the comparison was another crucial point. If humans were being equated to animals, this could be seen as refusing to accord Jews the status of fellow human beings, a classification that also 
lay at the heart of National Socialist antisemitism. If the two were being equated, it was argued before the Federal Constitutional Court that this also constituted a violation of Article 1 of the German Basic Law [Grundgesetz], which states that "the dignity of the human being is inviolable" (Art. 1).

The understanding of the workings of comparison and metaphor that emerges from the arguments is instructive with respect not only to the question of "equating," but also in what it suggests about the directionality of the metaphorical mapping and relationship of tenor to vehicle. I will consider each in turn.

The German and Austrian lower courts had all agreed with the complainants that the comparison did in effect equate human beings and animals. PETA argued that only certain aspects of a shared fate were being compared and that both humans and animals had the capacity to suffer, which was the main point of the campaign. Even if it were the case that the suffering of the two were equated, this would not constitute a humiliation of human beings, since PETA believed that animals were not inferior to humans (BVerfG par. 10).

In the Austrian case, the Supreme Court of Justice reached a different conclusion. The justices rejected the contentions that (1) Jews were being equated to animals, and (2) the "content" of the equation was National Socialist in nature. In the court's eyes, an "average informed viewer" could not possibly misunderstand the exhibition's message as asserting the Jews were animals, since the connection of Jews to animals intended to say "only that Jews were treated like animals" (OG p. 5).

In my opinion, the Austrian court got it right, but for the wrong reasons. Taking at face value PETA's claims about the thrust of the campaign, one would assume that the intended message of the exhibition was: "Animals are being treated [now] as Jews were [then]." In other words, the animals are being "seen as" Holocaust victims. It is remarkable, however, that all actors in the lawsuits, including the justices of the two supreme courts, took it as given that the metaphor worked in both directions and included the implication: "Jews under National Socialism were treated as animals are today." In other words, the situation (and system of associated commonplaces) of animals, which is actually the tenor of the original metaphor, is transformed into a secondary vehicle that is then projected onto the situation of the original vehicle (the situation and system of associated commonplaces of Holocaust victims).

In a special page titled "On [the] Comparison" [Über den Vergleich], the German PETA website addresses the question of comparability directly and takes up the double-sidedness of what it calls the "analogy." On the one hand, it argues the legitimacy and necessity of speaking out against cruelty to animals. Since animals cannot speak for themselves, and the message is not resonating publicly the way PETA considers necessary and fitting, "We therefore have no other 
choice but to compare the barbarism against animals with similar forms of extreme human suffering that are more familiar to us, in the hope that [such suffering] will then be clear to all and provide reason to act." On the other hand, the website correctly points out that "Analogies to animals are frequently used these days to [point out] the cruelties of the Holocaust" (PETA Deutschland - Comparison).[12]

In the court cases, the nature of the linkage between vehicle and tenor, while assumed to be reversible, is also at issue. In the passage quoted above, the German Federal Constitutional Court cites the lower court's finding that the comparison "appeared arbitrary" and therefore instrumentalized the Holocaust. The Austrian Supreme Court of Justice also considered the issue and conceded that "at least that portion of the campaign's public that rejects questions of animal protection will see the juxtaposition as totally overdrawn and unacceptable" (OG p. 5). It is notable here that the public, rhetorical nature of the exhibition (and hence of the metaphor) is acknowledged, and that the public reaction may play a role in the courts' deliberations. Later in its decision, the court returns to the issue of linkage, asking whether (1) the goals of the exhibition and the means it uses to achieve these goals are crassly disproportionate, or (2) "the bases of the comparison (the factual circumstances [they reflect]) differ so much that it would be possible to speak of a thematically totally mis-applied ('far-fetched') comparison" (OG p. 6).

From PETA's perspective, of course, the mapping is anything but arbitrary. The Holocaust and the treatment of animals in contemporary industrial livestock farming and slaughterhouses are parts of the same whole - instances of "sibling synecdoche" the whole of which is not only the suffering of sentient beings but the policies and practices of "species-ism," since the National Socialism denied Jews human status. This would both justify the linking of the two terms (since their connection is not manufactured but inherent in "the world") and explain why the mapping can operate bidirectionally, since each would be an instance of the same principle, part of the same whole. Of course, this does not exhaust PETA's reasons for structuring the exhibition as it did, and we will return to other aspects in the final part of the paper.

Recalling the distinction between the workings of metaphor (where the tenor and vehicle come from different lexical or conceptual domains) and metonymy / synecdoche (where the mapping occurs within a single domain), we see the court wrestling with the issue of where the connection becomes so tenuous that it breaks. In this case, the court held that, although the comparison was drastic - as was required in order to garner attention in a "society overly inundated by

[12] James Agee's “A Mother's Tale," to name one example, tells of cattle transported to a horrible place of industrialized torture and death from which one manages to return and report, only not to be believed (Agee). I am not aware of any protests against this or similar texts. 
advertising stimuli" - and although the exhibition might be considered "impious, tasteless, overdrawn and even immoral," it was not illegal (OG p. 6).

The Austrian court thus overturned the injunction against the exhibition, citing both the technical grounds of the complainants' lack of standing and substantive grounds, many of which I have just discussed. The German court also dismissed the constitutional challenge, finding that the exhibition did not impinge on the "human-ness" provisions of the Basic Law; but in refusing to hear the consitutional issue, the court in effect upheld the lower courts' ban on the exhibition.

The discussion of these controversies helps to establish a "tool kit" for understanding and analyzing metaphor and metonymy that invokes the Holocaust. But I have not yet mentioned what is probably the most prevalent single figuration of the Holocaust - the word "Auschwitz." Adorno's theorem: “... nach Auschwitz ein Gedicht zu schreiben, ist barbarisch ..." [after Auschwitz, to write a poem is barbaric] is perhaps the most widely-quoted (and widely misunderstood) example of this kind of usage (Adorno 49). Indeed, the phrase "after Auschwitz" has taken on a life of its own and figures prominently in many discourse types including seminal scholarly discussions of Holocaust memory and representation. [13]

How does the figuration invoked by "Auschwitz" fit into our discussion so far? As we shall see later, its figurative status is not merely a technical matter. Daniel Schwarz comments that in speaking of lyric poetry, Adorno actually was using "a metaphor for imaginative literature" in general (Schwarz 22). In our terms, this is not a case of metaphor in the strict sense, but of synecdoche, since poetry, as a part of the whole of imaginative literature, stands for that whole. But what about the term "Auschwitz" itself?

R. Clifton Spargo's stimulating discussion of Emmanuel Levinas construes the term as a moral imperative and challenge by virtue of its being

a historical metonym for J'accuse - to be stated, as it were, in the legal and cultural courts of all Western countries not only against the direct perpetrators of genocide but against all who, having done effectively little to prevent or curtail genocide, would still presume upon positive traditions of justice as though the legitimacy of such European traditions and the states upholding them had not been severely impaired by the cumulative legacy of antisemitism, that philosophical crime Levinas calls "hatred of the other man" (Spargo 180).

Primarily, however, "Auschwitz" functions as a synecdoche for the Holocaust, a part of the whole which in some contexts it has almost come to subsume. For many, Auschwitz incorporates - has incorporated -

\section{The Case of "Auschwitz"}


the whole of the Holocaust. Of course, the name "Auschwitz" is also part of a more complicated relation. It is a metonym for the horrific events that took place in the concentration camp and mass murder site that lends the figure its name. And, as Spargo says, it is a one-word argument and call to action, although the nature of that action is open to interpretation as it is invoked by different actors in different contexts.

Daniel Levy and Natan Sznaider point out some of the changing notions of what is being suggested by the metonym "Auschwitz".[14] Using German responses to the Kosovo crisis and interventions of 1999 as an example, they show that the understanding of "Auschwitz" as a place where terrible crimes were committed was augmented by seeing it as an instance where humanitarian intervention would have been required but had not taken place. The shift allowed (or was made possible by) Germans' revisioning themselves from perpetrators to world citizens obligated to help. Germany, they argue, has now become one of the Western allies, but the invocation of "Auschwitz" allows Germans figuratively and anachronistically to imagine themselves as "better than" the Allies in World War II for having in fact acted to prevent genocide in Kosovo (Levy and Sznaider 189ff).

As Helmut Dubiel points out, this multiple valence had already been evident in 1983, when the Federal Green Party, newly elected to the German Bundestag, opposed NATO re-armament plans in Germany (Dubiel 193-194). Both Joschka Fischer and Heiner Geißler (then secretary general of the senior government coalition party CDU and a cabinet minister) invoked "Auschwitz" to justify their positions, with Geißler accusing the Greens of ignoring the fact that, without the pacifism of the 1930's, Auschwitz would not have been possible ("Egal wie" 26-27).[15]

Dubiel sees in this debate a crucial break with the past, since previously the conservative parties had observed a "taboo" against invoking the crimes of National Socialism. Thereafter, the threshold of inhibition was significantly lower. As Dubiel says, Geißler and Fischer both use "Auschwitz" - Dubiel puts the word into quotation marks even he is writing about the place and not just the metonym - as if it were a "seemingly self-explicative metaphor." Despite the protestations especially of Fischer that he did not intend to question the uniqueness of National Socialist crimes by irresponsibly analogizing from the Holocaust to the stationing of Pershing II missiles, both he and Geißler, in Dubiel's view, are not really concerned with a "debate

[14] The changing perception in Poland on who the principal victim group in "Auschwitz" was, is a case in point, with its own background, sensibilities, and dynamic.
[15] The parliamentary minutes of the debate are worth reading and analyzing, especially for the reflections on the nature of comparison and metaphor that all sides reveal; but this would overstrain the limits of this paper (Deutscher Bundestag). 
about the historical reality of 'Auschwitz" but rather with garnering support for their respective political positions. From this point on, aspects of National Socialist crimes, particularly of the Holocaust, would be easily accessible but unstable building blocks of political rhetoric and the subject of wrangling over who can legitimately employ them.

As a way of concluding this section of my paper, I want to say a word about myth. I am not talking about the "Auschwitz myth" in the sense that Holocaust deniers use it (Weber).[16] The myth of which I am talking is, however, a fiction of sorts, just as metaphor is a fictional structure whose syntactic pendant lies in the contrary-to-fact conditional of the subjunctive mood. To metaphorize is to say simultaneously that we know that $\mathrm{X}$ is not $\mathrm{Y}$, but we would like to imagine the situation as if it were (Ricoeur, Metaphor 251-253). And as I have already discussed, metaphor is also both a narrative and an argument. Myth is related to metaphor in that it is also a story about something that might have been but wasn't (exactly); but in the case of myth the story of the metaphor is elaborated, and the tension between the consciousness of pretending and the allegiance to the story as binding shifts. That is why Ricoeur refers to myth as "metaphor taken literally" (Ricoeur, Metaphor 251), or as I would have it, metaphor in which we believe. For Ricoeur and others, the problem arises when the movers or receivers of metaphor-as-myth lose sight of its status as "as if." Then it ceases to be metaphor, as Enzensberger asserted was the case in his portrayal of Saddam Hussein, and purports to be literally true.

The concluding section of the paper considers whether and how one can judge the ethical qualities of comparison in general and metaphor in particular. A putative ethics of metaphor and comparison would be, in this case, a subset of the ethics of rhetoric, since the comparisons and mappings examined in this paper are propositional, seeking to advance an argument, many of them in an explicitly public and political setting.

We have seen how the comparative process, particularly as employed in metaphor, involves mapping concepts and structures from one conceptual / lexical domain to another. (In the cases of metonymy and synecdoche, the mapping remains within one domain.) Of course, one of the most important virtues (and potential vices) of such figuration lies in the fact that its force is also emotionally evocative (Denham 165). The effect of metaphor depends on a combination of conventionality and innovation. Metaphor is conventional not only when it employs commonplaces (such as comparing stages of the human life cycle to times of day, or seasons, or phases of plant life), but

\section{The Ethics of Comparison}

[16] Please note that the Mark Weber in question spells his last name with one " $b$ ". 
because, to be understood in the way in which its author intends it, the "system of associated commonplaces" it invokes must be shared by those offering and receiving the metaphor. At the same time, good metaphor identifies and creates something new - a new connection (and way of seeing) something that we had not thought of before.

And although the mapping from vehicle domain to tenor domain must be capable of identification that reduces the tension between the two realms, unless the metaphor is "dead" (as in the conventional sense of a furniture "leg," which is a lexicalized concept for which there is no other term) or has been converted to myth (in which case the relationship is "believed" to be inherent and binding), the tension remains ultimately unresolved.

Therefore, it is important that the mapping "fit" - that is, those elements of the vehicle domain's system of associated commonplaces that the metaphor activates must be seen to match the "similar" elements of the tenor domain. Moreover, the vehicle elements must be logical and coherent among themselves; "mixed metaphors" undermine themselves by being either ridiculous or incomprehensible.

It is important to understand that metaphor has the power not only to point out, but also to create similarity, which is another way of saying that, just as it draws on conceptual structures, it also creates structures for thinking about and understanding the world. Because the similarity between things asserted by metaphor is an imagined and imaginary quality ("If A were like B in these respects, then..."), "there is a sense in which the metaphor - if it is a good one - brings it about that they are experienced as similar (Denham 309). As Ted Cohen puts it, "seeing A as B" creates "a new entity" (Cohen 6). And as Ricoeur, drawing on Black, states: "metaphor creates the resemblance rather than finding or expressing it" (Ricoeur, Metaphor 236).

So far, what I have been summarizing and describing have been aspects of the operation and efficacy of metaphor, but not its ethical qualities. In fact, metaphor's "eligibility" to be considered in terms of its ethical behaviour stems from its ability to state and point out truths. For if metaphor (as a process) were non-discursive and non-cognitive, without referential value or truth claim (and the potential for truth content), then individual metaphors (including non-linguistic ones, and the ways in which they are configured, offered, and received) could not be tested for propriety and ethical status (Denham 334). Assuming that metaphor partakes of and contributes to public, political discourse, and that it does claim to point out and establish things true and important, what must one consider in order to come to a considered judgement of what makes it ethical or unethical?

First, there is the "duplicitous" nature of metaphor itself, which, as we have seen, brings together two elements in a way that temporarily and imaginarily masks their differences while simultaneously pointing to the existence of those very differences and hence unmasking its contrary-to-fact-ness. For Ricoeur, the failure to "expose" 
metaphor's doubleness or duplicity would constitute an abuse of metaphor (Ricoeur, Metaphor 252).

In the opening paragraph of his article "The Use and Abuse of Metaphor," Douglas Berggren, who also figures in Ricoeur's analysis, points out "the fact that metaphor constitutes the indispensible principle for integrating diverse phenomena and perspectives without sacrificing their diversity" (Berggren, Part I, 237). Berggren's statement speaks to two important aspects of metaphor (and comparison in general) that also have implications for judging their ethical qualities. First, metaphor does make a truth claim and states a truth content, doing so in a unique way. Second, while bringing together "diverse phenomena" (in technical terms, the two conceptual domains), metaphor also keeps them apart. I understand the phrase "without sacrificing their diversity" to mean "without ignoring or eliding their particularity and singularity." [17]

The duplicitous nature of metaphor cannot be removed, but it can be countered by our being aware of it. Such self-awareness is in fact crucial for employing Holocaust metaphors responsibly. The key question here, I think, is whether such invocations of the Holocaust "do justice" to the Holocaust, that to which they are being compared, to the persons implicated, and to the metaphor's "aim" or "thrust."

In The Ethics of Memory, Avishai Margalit draws a distinction between "ethics" and "morality", a distinction he derives from his reading of Jewish scripture and tradition. Family relations, he claims, should be guided by "caring" and "loyalty" that arise out of the Jewish sense of having been delivered from bondage; relations with nonmembers of the family, on the other hand, should be governed by "respect" that derives from "the debt of gratitude all humanity owes God for having been created in His image" (Margalit 72-73). I find Margalit's distinction interesting and provocative (in the good sense) but not entirely persuasive. Even by his definition, it is human beings' common humanity - and the mutual respect which that entails - that governs all interpersonal relations - with additional considerations and obligations attaching to those with whom we live and interact on a more intimate basis.

Margalit's analysis works with the question "Who Is My Neighbor?" (Margalit 40-47), a question that also figures centrally in Spargo's analysis of Levinas, where he takes on Levinas' concepts of identity and alterity, discussing them also in relation to the functioning and ethical function of metaphor (Spargo 179-242, 294-302). Precisely by virtue of its structure of inherent tension between a similarity that tends towards identity on the one hand, and a particularity

[17] Berggren further specifies this relationship by speaking of our "intellectual ability to play two diverse language games stereoscopically. While construing one mode of reality in terms of another, the autonomy of each must be preserved even while they are being simultaneously assimilated or integrated" (Berggren, Part II, 471). 
of difference that risks not being capable of relationship, metaphor reflects and instantiates the nature of human relationships: "Levinas positions the stranger as that figure for the other who is significant even though, or precisely because, she is also at a distance" (Spargo 189).

In order to do justice to humanity's belonging together in strangeness, language (in this case: metaphor) "must always be positioned on a threshold of meaning, at a 'door thus both open and closed,' which Levinas also calls 'the extra-ordinary duplicity of the Enigma"' (Spargo 207). In the framework of this essay, we are dealing here with an acknowledgement of a common humanity within which estrangements and particularities are present; with the necessity of acknowledging also and particularly the presence of those estrangements; and with metaphor as a structurally well-suited means for calling to mind that double structure. Precisely because of its structural duplicity, then, metaphor can and should be a particularly apt medium for ethical behaviour through and in language. The potential of metaphor is also its risk - the betrayal of the stranger, the failure to behave ethically - consciously, responsibly and respectfully.

In attempting to encapsulate briefly the nature of ethical relations, I have begun with the "other," the "stranger." In the context of metaphorical structure, the stranger occupies the position of the metaphorical vehicle, that for which we reach out, and which we then try to domesticate and bring home, by connecting and applying it to a situation dear to our heart.[18]

The stranger is also that person who is implicated in the system of associated commonplaces within which the particular metaphorical vehicle resides. Thus, in the case of metaphors and comparisons invoking the Holocaust and mapping its events, situations, actors, relationships, and emotions onto the situation of Palestinians, or some other ethnic or nationally-constituted group, there should obtain a sense of responsibility and respect for those "others" - the victims of the Holocaust - whose often nameless sufferings we call upon to shed light on the tenor domain.

A condition for the required attitude of respect and responsibility is empathy, the ability to put oneself into the other's situation, to "see the other as ourselves." But just as metaphor - seeing something "as" something else - simultaneously calls to mind the situation of the tenor and the vehicle, empathy involves our being able to understand others' and their sensibilities and concerns, something that is possible only if we understand and respect ourselves: Empathy, I suggest, begins "at home."

[18] I have taken the concept of "domestication" from Lawrence Venuti, whose analysis of the process and ethics of translation deserves more elaboration than is possible here, particularly because of the structural (and ethical) similarities between the processes (productive and receptive) of translation and metaphor (Venuti). 
LaCapra captures the doubleness of this situation - and its precariousness - in the following passage:

Empathy itself, as an imaginative component not only of the historian's craft but of any responsive approach to the past or the other, raises knotty perplexities, for it is difficult to see how one may be empathetic without intrusively arrogating to oneself the victim's experience or undergoing (whether consciously or unconsciously) surrogate victimage (LaCapra 182).

Ulrike Jureit and Christian Schneider point out how important it is to understand the situation (and motivation) of those who cast themselves as Holocaust victims. In Gefühlte Opfer. Illusionen der Vergangenheitsbewältigung [Casting Ourselves as Victims: Illusions of 'Mastering the Past'], they argue that the culture of memory in Germany is dominated by a wish to (over)identify with the victims (Jureit and Schneider 10). To the extent this is true, it would represent an overbalancing in which one's own cultural positionality and the particular responsibilities it is often assumed to impose, fades in comparison when the spotlight of the victims'fates is projected onto it.

LaCapra introduces the idea of "authenticity" into the debate, something that he defines as "being true to the self and not being selfdeceived (or for Sartre, in bad faith)." Although LaCapra does not consider this "an ethical or moral value but a transcendence of ethics," I see it as one of the preconditions for ethical behaviour and for offering ethical comparisons, because it acts as a safeguard in those who did not undergo the Holocaust against over-identifying with its victims (LaCapra 201).

In the context of rhetoric, the standing of the rhetor is important for the reception of her or his argument. By standing I do not only mean personal character, qualifications, reputation, nor even blood-line, although these are often deemed relevant by those advancing or evaluating an argument (Smith). These days, it is now all too predictable that those who have been, or think they might be, accused of behaving unethically or even antisemitically in their invocations of the Holocaust, will putatively "immunize" themselves against such accusations by referring to their Jewishiness, or the fact that their parents or grandparents were Holocaust victims. The notion that a Jew cannot also be an antisemite is itself both untrue and vaguely antisemitic, since it draws on and perpetuates the notion that Jews are a single group whose members cannot help but support it.

In an extremely helpful passage, Denham sees the capacity for empathy as a crucial condition for ethical behaviour. From her perspective, "the reliability of our moral judgements depends critically on our understanding of the concerns and interest that subvene the moral aspects of things - our understanding of others' inner lives." She goes on to elaborate other qualities and capacities that make up "moral judgement": 
A sympathetic imagination, is not, of course, the whole of moral wisdom, or even the whole of excellence in moral judgement. This also requires, inter alia, an understanding of relations of means and ends, an ability to weigh and balance competing ends, and an appreciation of the scope and limits of human agency and responsibility.

In addition, according to Denham, this kind of "imaginative responsiveness" "reveals others' purposes as possessed of value (and as possessing values of specific kinds)" (Denham 229). These are precisely the qualities that go into producing Holocaust comparisons that meet the test of ethical behaviour.

Denham's inclusion of "an understanding of relations of means and ends" is relevant to the way in which the mapping from domain to domain takes place in metaphor that is ethical. The mover of such metaphor weighs conscientiously the elements of a potential Holocaust comparison, deciding, on the basis of well-researched knowledge of the facts, what fits and what does not. Here the judicial principle of "proportionality" is relevant. For a metaphor to be "undeceptive" (Margalit, Ethics 49), the overall magnitude, scope, and intensity of the events and circumstances being compared should not be radically out of alignment, unless the intended effect is to highlight this very mismatch.

A final element in my very tentative outline of factors in the ethical use of metaphor is the thrust of the comparison, including an informed sensitivity as to how a potential metaphor can be (mis)read, especially by those who were made to suffer in the Holocaust and their family members. This does not mean that such comparisons should not be made, even if they are offensive, as long as they are undertaken conscientiously, empathetically, and after having weighed the possible consequences. Those who wish to use Holocaust comparisons ethically will do their best avoid thereby giving the impression that they are belittling or denying the Holocaust or demeaning or mocking its victims and their descendants and families.

Again, the issue is not whether such comparisons instrumentalize the Holocaust. Everyone who "uses" the Holocaust to "teach from the past" instrumentalizes it. The issue is whether one does so responsibly and honestly, so as to "do justice" to that which one is invoking and evoking. And here, we can ask whether deceptive manipulation is the goal and the method.

I now want to return to the cases of the PETA posters and the metonym of "Auschwitz," applying to them the proposed principles for ethical metaphor. Again, a disclaimer: I realize that these principles cannot be considered either prescriptive or exhaustive. On the contrary, they no doubt require correction, elaboration, and criticism to even come close to achieving their aspirations. 
One factor in the ruling of the Austrian Supreme Court of PETA Revisited Justice was its finding that "the truth of the respective factual situation behind the images... is indisputable" (OG p. 5). Although the court lists, in its initial inventory, the "accompanying text" for each image, it is interesting and telling that the court considered the images, but not the words of the exhibition. In this regard, the text for poster 7 , which features as its "headline" the exhibition's title, is particularly interesting. It reads as follows in the English and German versions:

\begin{tabular}{lll}
\hline English & German & Translation of German \\
\hline $\begin{array}{l}\text { During the seven years between } \\
1938 \text { and 1945, 12 million people } \\
\text { perished in the Holocaust. }\end{array}$ & $\begin{array}{l}\text { Zwischen } 1938 \text { and } 1945 \text { starben } \\
\text { Holocaust. }\end{array}$ & $\begin{array}{l}\text { Between 1938 and 1945, 12 million } \\
\text { people died in the Holocaust. }\end{array}$ \\
$\begin{array}{l}\text { The same number of animals } \\
\begin{array}{l}\text { is killed EVERY 4 HOURS for } \\
\text { food in the U.S. alone. (The Holo- } \\
\text { caust on Your Plate Slide 7) }\end{array}\end{array}$ & $\begin{array}{l}\text { Genauso viele Tiere werden für } \\
\text { den menschlichen Verzehr jede }\end{array}$ & $\begin{array}{l}\text { Exactly as many animals are killed } \\
\text { in Europe every hour for human } \\
\text { consumption. }\end{array}$ \\
\hline
\end{tabular}

One of the defences that PETA mounted in its efforts to disqualify the complainant group (whose members in each case were all Jewish) was that "the concept 'Holocaust' did not signify the persecution solely of the Jews"; and that human victims depicted on the posters could not be definitively identified as Jews (BVerfG par. 12). Previous to its disputing the standing of Jewish groups, however, PETA Germany had attempted in vain to enlist the support of the Central Council of Jews in Germany for the poster campaign. In a letter to then Chair Paul Spiegel, PETA's youth outreach coordinator, Matthew A. Prescott, states his bona fides as a relative of Holocaust victims and survivors and asks for "a few lines of goodwill" from Spiegel (Prescott).

A conventional part of almost every document from or on behalf of PETA's "Holocaustizing" is the listing of Jewish authors (such as Isaac Bashevis Singer and Elie Wiesel) and the appeal to the family tree of the author(s) of the document or exhibition. The pro-PETA article "Can the Treatment of Animals Be Compared to the Holocaust," for example, begins with an entire section on the comparison's (and its supporters') pedigree and the observation that the "comparison between the Holocaust and the treatment of animals is especially dramatic when offered by culturally eminent Jews, or else actual Holocaust survivors" (Sztybel 98-99).

There seems, then, to be a tendency on the part of PETA and its supporters to play fast-and-loose with the "Jewishness" of the Holocaust; it is acknowledged where it is convenient and would seem to lend credibility and weight to PETA's campaign, but it is denied where it threatens to be an obstacle. In saying this, I do not doubt the sincerity of those Jewish members and supporters of PETA whose 
motivation is bound up with their understanding of the legacy of the Holocaust; but the organization's overtly tactical use of the criterion of Jewishness does raise questions.

The questions become more urgent with reference to the number of victims. The article just quoted, which lists 39 points of comparison between the Holocaust and the treatment of animals, compares the "estimated 6 million dead Jews" of the Holocaust to the "[1]iterally billions of animals (...) killed each year for the sake of human enjoyment and convenience alone" (Sztybel 112). On the poster in question, however, the number given is twelve million. This functions as a comparator for two different calculations in the Englishlanguage and German-language versions of the poster. Both versions equate it to the killing rate of animals for food, but the calculation apparently yields a 1:4 ratio in the United States, and a 1:1 ratio in Europe. In terms of metaphorical mappings, one wonders whether the supposed vehicle domain (the Holocaust), instead of being projected onto the tenor domain of animal slaughter, is in fact "receiving" the number twelve million from the latter, so that it appears the numbers of Holocaust victims has special relevance to animal rights.

Just before the PETA poster campaign was to begin in Germany, Der Spiegel ran a four-page article on the exhibition and interviewed PETA representatives. Asked about the time span indicated for the Holocaust (1938 to 1945), the head of PETA Germany, Harald Uhlmann, indicated that he had received it from headquarters in the United States. The Spiegel journalist suggests that "it's not really important" to Uhlmann: "They needed a time span and a number. Twelve million people, twelve million animals" (Goos 227). If this is indeed the case, then the Austrian court might well have found that PETA had been dishonest in its portrayal of the Holocaust.

As becomes clear from other statements by PETA representatives, the organization's main concern is how to garner attention for its message. Accuracy is not a primary concern, according to Jürgen Faulmann, PETA Germany's campaign director: "In the animal rights movements there has never been a discussion about whether it is wrong or right with regard to content. There have always only been discussions about whether it is strategically right to do it - whether it's more detrimental or helpful" (Goos 229).

From this analysis, it is clear that:

(1) the Holocaust and its victims are not at the forefront of PETA's concerns when employing comparisons to this genocide; rather it functions as part of the organization's toolkit for obtaining notoriety.

(2) For PETA, the ends justify the means. Historical accuracy is less important than "making the message fit." This means that the mapping from one domain to the other can be (and in this case is) based on invented data that masquerade as facts. In an academic setting this would constitute a breach of academic honesty. 
(3) PETA's statement that "it was never our goal to humiliate the victims further" (Newkirk) rings hollow when one looks at poster 1 (reproduced earlier in this paper), which depicts emaciated and fully naked Holocaust victims, including their faces and genitals.

My intention here is not to demonize PETA. Unfortunately for all concerned, however, the organization's "Holocaust on Your Plate" campaign incorporates and illustrates many of the key elements of unethical use of Holocaust comparison. This does not detract from the organization's legitimate concerns regarding the treatment of animals. It does, however, undermine its claim to be an organization purportedly concerned with ethics, since it is so ready to use unethical means to advance its ends.

Lastly, we come to the use (and abuse) of "Auschwitz." Names are important, and as LaCapra correctly observes, "no names or innocent or politically neutral" (LaCapra 206). Just as the term "Holocaust," originally a metaphor of questionable theological provenance, has established itself to the point that it is lexicalized and irrepressible, the synecdoche of "Auschwitz" for the Holocaust in general is likely beyond recall (Young 84-88). Like Adorno, most of those who use "Auschwitz" as shorthand for the Holocaust do so in good faith. And yet, the rhetoric of "Auschwitz" is not without its consequences. It is more emotionally evocative than the whole of which it is admittedly an important part. But by threatening to subsume its superordinated concept, it flattens the Holocaust, oversimplifies it, and so distorts it. Although the large majority of those who were murdered in the Holocaust did not die in Auschwitz (by which most people in North America mean the camp and mass-murder facilities at AuschwitzBirkenau), the reduction of the shootings, starvation, and mobile and stationary mass-murder sites to one evocative location misrepresents the nature of the phenomenon in ways that can only be balanced if those who use the synecdoche explicitly clarify for what it stands.

In a way, however, the treatment of "Auschwitz" as name, place, and synecdoche can be an example for how to approach the figuration of the Holocaust in general. I am suggesting that this pars pro toto is a part of the whole of Holocaust figuration - both in the positive way the particular stands for the overriding (I hesitate to speak of the "universal") and in the brokenness of the mapping. To use an explicit analogy: Auschwitz is to the Holocaust as the Holocaust is to genocide. Each element at each "level" has its specificities that make it unique and its general features that are shared with other elements within its level (Auschwitz with, say, Treblinka; or the Holocaust with Darfur).[19]

[19] There is not space here to go into the political and economic implications of the special focus on Auschwitz as concept and place. Suffice it to say that, within the community of memorial sites and museums, within Poland, in the rest of Europe, and world-

\section{Reclaiming "Auschwitz" as Synecdoche?}


To insist on uniqueness is not, as some would have it, to preclude comparison; nor is it or should it constitute an attempt to create, in Michael Rothberg's terms, "a hierarchy of suffering (which is morally offensive)"; nor does it remove "that suffering from the field of historical agency (which is both morally and intellectually suspect" (Rothberg 9). In this case, the uniqueness is itself an ethical obligation - the duty to investigate and analyze conscientiously, without "flattening" the layered relationship of persons, places, motives, events, and sequences (both within and between genocides and other horrible instances of humans oppressing and murdering humans).

To make the connections while remaining aware of the "brokenness" of the relationship - of the "duplicitous" structure of metaphor that is itself understood figuratively - provides a possibility for understanding that puts ethics - understood as respect and responsibility for oneself and one's fellow humans - at the centre of the process.

\section{Works Cited}

Adorno, T.W. "Kulturkritik und Gesellschaft." Lyrik nach Auschwitz? Adorno und die Dichter. Ed. Petra Kiedaisch. Universal-Bibliothek, 9363. Stuttgart: Reclam, 1995. 27-29.

Agee, J. "A Mother's Tale." The Collected Short Prose of James Agee. Ed. Robert Fitzgerald. Boston: Houghton Mifflin, 1968. 221-243.

Alexander, J.C. "The Social Construction of Moral Universals." Remembering the Holocaust. Oxford / New York: Oxford University Press, 2009. 3-102.

Augstein, R. “Kommentar: Kein Hitler." Der Spiegel 10/1991. 4 March 1991: 160.

Bauer, Y. Rethinking the Holocaust. New Haven / London: Yale University Press, 2001.

Berggren, D. "The Use and Abuse of Metaphor, I." The Review of Metaphysics: A Philosophical Quarterly 16.2 (1962): 237-258.

-. "The Use and Abuse of Metaphor, II." The Review of Metaphysics: A Philosophical Journal 16.3 (1963): 450-472.

Black, M. "Metaphor." Proceedings of the Aristotelian Society. New Series, 55 (1954-1955): 273-294.

B'nai Brith Canada. “The Unholy Alliance." National Post. 9 November 2010: 18.

Bundesverfassungsgericht. "Entscheidungen: BVerfG, 1 BvR 2266/04 vom 20.2.2009, Absatz-Nr. (1 - 29).” 20 February 2009. 25 November 2010 <http://www.bverfg.de/entscheidungen/rk20090220_1bvr226604.html>.

Cohen, T. Thinking of Others: On the Talent for Metaphor. Princeton Monographs in Philosophy. Princeton, NJ: Princeton University Press, 2008.

Denham, A.E. Metaphor and Moral Experience. Oxford Philosophical Monographs. Oxford: Clarendon Press, 2000.

Deutscher Bundestag. "10. Wahlperiode - 16. Sitzung." Bonn, Thursday, 23 June 1983. 1043-1055.

-. Grundgesetz für die Bundesrepublik Deutschland. September 2010. 23 December $2010<$ https://www.btg-bestellservice.de/pdf/10060000.pdf>.

Dubiel, H. Niemand ist frei von der Geschichte. Die nationalsozialistische Herrschaft in den Debatten des Deutschen Bundestages. München: Hanser, 1999.

“Egal wie. Pazifismus habe 'Auschwitz erst möglich gemacht' - Grobgeratenes von Heiner Geißler. Keiner kann so hart holzen wie der CDU-Minister." Der Spiegel 25/83. 20 June 1983: 26-27. 
Enzensberger, H.M. “Hitlers Wiedergänger.” Der Spiegel 6/1991. 4 February 1991: 26-28.

"Gaza War Protest [Nazism = Zionism | Zionism = Nazism]." http://zombietime. com/gaza_war_protest/, accessed 22 November 2010.

Gerhardt, Ch. "The Ethics of Animals in Adorno and Kafka." New German Critique 33.1 (2006): 159-178.

German Bundestag. Basic Law for the Federal Republic of Germany. Print version as at: April 2010. 27 January 2010. 23 December $2010<\mathrm{https://}$ www.btg-bestellservice.de/pdf/80201000.pdf $>$.

Goos, H. Ein Krieg für Tiere. Die Mitglieder der Tierrechtsorganisation Peta sind moderne Guerilleros. Sie kämpfen mit aggressiver Werbung, provizierendem Witz und nackter Prominenz. In ihrer jüngsten Aktion vergleichen sie die Massentierhaltung mit dem Holocaust. 12/2004. 15 March 2004. 22 December 2010 <http://wissen.spiegel.de/wissen/ image/show.html?did=30220155\&aref=image035/E0411/ROSP2004012 02260229.PDF\&thumb=false $>$.

Jäckel, E. "Die elende Praxis der Untersteller. Das Einmalige der nationalsozialistischen Verbrechen läßt sich nicht leugnen." "Historikerstreit”. Die Dokumentation der Kontroverse um die Einzigartigkeit der nationalsozialistichen Judenvernichtung. München: Piper, 1987. 115-122.

Jureit, U. and Ch. Schneider. Gefühlte Opfer. Illusionen der Vergangenheitsbewältigung. Stutttgart: Klett-Cotta, 2010.

Kansteiner, W. "The Rise and Fall of Metaphor: German Historians and the Uniqueness of the Holocaust." Is the Holocaust Unique? Perspectives on Comparative Genocide. Ed. Alan S. Rosenbaum. 2nd edition. Boulder, CO: Westview, 2001. 221-244.

Kubczak, H. "Metaphern und Metonymnien als sprachwissenschaftliche Untersuchungsgegenstände." Zeitschrift für deutsche Philologie 105 (1986): 83-99.

LaCapra, D. History and Memory after Auschwitz. Ithaca, NY: Cornell University Press, 1998.

Lakoff, G. and M. Turner. More than Cool Reason: A Field Guide to Poetic Metaphor. Chicago: University of Chicago Press, 1989.

Levy, D. and N. Sznaider. Erinnerung im globalen Zeitalter: Der Holocaust. Edition Zweite Moderne. Frankfurt/Main: Suhrkamp, 2001.

Margalit, A. and G. Motzkin. "The Uniqueness of the Holocaust." Philosophy and Public Affairs (Winter 1996): 65-83.

Margalit, A. The Ethics of Memory. Cambridge, MA: Harvard University Press, 2002.

Newkirk, I. "PETA apologizes for Holocaust comparisons." 13 May 2005. Jweekly. 25 November $2010<$ http://www.jweekly.com/article/full/ 25964/peta-apologizes-for-holocaust-comparisons/>.

Oberster Gerichtshof. "Entscheidung 6Ob321/04f." 12 October 2006. Bundeskanzleramt / Rechtsinformationssystem. 21 December $2010<\mathrm{http}: / /$ www.ris.bka.gv.at/Dokumente/Justiz/JJT_20061012_OGH0002_ 0060OB00321_04F0000_000/JJT_20061012_OGH0002_0060OB00321_ 04F0000_000.pdf>.

—. "PETA ersucht Unterstützung des Zentralrats der Juden zur Kampagne 'Holocaust auf Ihrem Teller.' 18 November 2003. PETA-Deutschland. $<$ http://www.peta.de/web/peta_ersucht.1539.html>.

—. “Über den Vergleich.” n.d. PETA-Deutschland. 25 November $2010<$ http:// special.peta.de/holocaust/analogy>.

Power, S. “To Suffer by Comparison?” Daedalus 128.2 (Spring 1999): 31-66. 
Prescott, M.A. “[Letter to Paul Spiegel].” 3 November 2003. 28 December 2010 $<$ http://special.peta.de/holocaust/zentralrat2.pdf $>$.

Ricoeur, P. "Memory and Forgetting." Questioning Ethics: Contemporary Debates in Continental Philosophy. Ed. Richard Kearney. London: Routledge, 1998. 5-11.

- . The Rule of Metaphor: Multi-disciplinary Studies of the Creation of Meaning in Language. Trans. Robert Czerny. University of Toronto Romance Series, 37. Toronto: University of Toronto Press, 1977.

Rothberg, M. Multidirectional Memory: Remembering the Holocaust in the Age of Decolonization. Cultural Memory in the Present. Ed. Mieke Bal and Hent de Vries. Stanford: Stanford University Press, 2009.

Schwarz, D.R. Imagining the Holocaust. New York: St. Martin's Press, 1999.

Smith, C.R. "Ethos Dwells Pervasively: A Hermeneutic Reading of Aristotle on Credibility." The Ethos of Rhetoric. Ed. Michael J. Hyde. Columbia, SC: University of South Carolina Press, 2004. 1-19.

Spargo, R.C. Vigilant Memory: Emmanuel Levinas, the Holocaust and the Unjust Death. Baltimore: The Johns Hopkins Press, 2006.

Stephan, C. "An der deutschen Heimatfront." Der Spiegel 10/1991. 4 March 1991: 238-239, 242, 244-245.

Stone, D. “The Historiography of Genocide: Beyond 'Uniqueness' and Ethnic Competition." Rethinking History 8.1 (March 2004): 127-142.

Sznaider, N. "Das große Mißverständnis: Finkelsteins Holocaust." Gibt es wirklich eine Holocaust-Industrie? Zur Auseinandersetzung um Norman Finkelstein. Ed. Ernst Piper. 2nd impression. Zürich / München: Pendo, 2001. 176-190.

Sztybel, D. "Can the Treatment of Animals Be Compared to the Holocaust?" Ethics \& the Environment 11.1 (2006): 97-132.

“The Holocaust on Your Plate." 25 November $2010<$ http://sztybel.tripod.com/ plate.pdf $>$.

Thiele, C. "Der Holocaust auf Ihrem Teller - Wanderaustellung macht Station beim Österreichischen Höchstgericht." 2007. Wirtschaftsrechtliche Blätter. 21 (2007). 263-267. 23 December $2010<$ DOI 10.1007/ S00718-007-0908-8>.

“Truthbombs on Israeli TV.” Adbusters. No. 92 (November / December 2010): Carnivalesque Rebellion. 22-28 November 2010. n.p.

Venuti, L. The Scandals of Translation: Towards an Ethics of Difference. New York: Routledge, 1998.

Weber, M. "Auschwitz: Myths and Facts." 2009. Institute for Historical Review. $21122010<\mathrm{http}$ //www.ihr.org/leaflets/auschwitz.shtml>.

Wülfing, W., K. Bruns and R. Parr. Historische Mythologie der Deutschen 1798-1918. München: Fink, 1991.

Young, J.E. Writing and Rewriting the Holocaust: Narrative and Consequences of Interpretation. Bloomington and Indianapolis, IN: Indiana University Press, 1988.

Zuckermann, M. Zweierlei Holocaust. Der Holocaust in den politischen Kulturen Israels und Deutschlands. Göttingen: Wallstein, 1998. 